of Australia, the farthest away, transmission must travel through twilight conditions whichever path round the world is used. It was not expected therefore that wave-lengths of 15 metres, using the daylight path, or 37 metres using the dark path, would give trustworthy service. Both can be used for short periods but their useful duration is limited and uncertain. The twilight band (25-29 metres) has been found to be the best. In the Indian zone it has been found that 17 metre transmissions are very satisfactory. In the case of Africa, as it lies almost due south, shorter wave-lengths are used during the day, intermediate wave-lengths at dusk and at nighttime 32 metre wave-lengths or even longer can be used. It is found better to divide Africa into two zones. The great circle path to Canada passes very near to the north pole and even in summer it is not a true daylight path. A satisfactory day wave for Canada is of the order of 19 metres, but night waves of 31 and 50 and sometimes as high as 70 or 80 metres have been used. The B.B.C. deserves great credit for having overeome so successfully many of the difficulties connected with the most ambitious project ever attempted in broadcasting.

\section{Standardisation of Electricity Supply}

IN a paper read on May 31 to a meeting of the Incorporated Municipal Electrical Assuciation (the I.M.E.A.), which was held in Liverpool, L. Romero discussed the standardisation of methods for distributing electricity and for its sale. He recently addressed a questionnaire to sixty of the largest municipal supply undertakings in Great Britain, and nearly all had replied explaining the systems they used and in particular the voltages which they adopted to supply their consumers. It was decided officially some years ago that the standard system of supply should be the alternating current system and that the standard pressure for domestic supply should be 230 volts. The replies received show that about a third of the municipal undertakings are maintaining voltages which are not standard and that the number of consumers using these voltages is rapidly increasing. The reason given for not adopting the standard is that the change would be expensive. This is a short-sighted policy, as it causes expense to consumers and is a definite obstacle in the way of cheapening electrical lamps and appliances. Several countries abroad also suffer from this lack of standardisation. Luckily, in Great Britain, the progress made in changing from D.C. to A.C. supply is much more satisfactory. Many people think that the supply of electricity should be managed on a national basis, their principal argument being the lack of standardisation that otherwise ensues. Presumably local authorities desire to manage their own electricity supply. Some of them would therefore do well to regard standardisation from a broader point of view.

\section{Electrification of Collieries}

ALtнобан great progress has been made during recent years in the electrification of collieries, about one third of the total power utilised is still generated mechanically. According to the Electrical Review of June 29, the total horse-power of the motors in use in collieries is now about $1,900,000$. This is equivalent to more than ten per cent of the capacity of all the plant connected to the public supply mains in Great Britain. Of the electricity used, only about thirty per cent is supplied by statutory authorities. Doubtless this percentage will rapidly increase, as power can be produced more cheaply at points away from the pithead where a more abundant water supply is available for condensing purposes. It is satisfactory to notice that, despite the increase in the use of electricity, the number of electrical accidents is steadily decreasing. This is due to the design of flame-proof structures and flame-proof apparatus. Owing to the high standards adopted by the Association of Mining Engineers, the costs of maintenance have also rapidly diminished. The fixing of minimum standards for illumination for portable lamps is a notable advance. We think that inventors ought to turn their attention to the development of a fixed lighting system which would be safe to use at all parts of the coal face.

\section{Interference with Radio Supply by Electric Lighting}

IT is well known that when direct current supply is used for electric lighting, the contacts of the switches and fuses often get badly corroded after a few years' operation. This usually causes little, if any, inconvenience in the lighting of the house or in the use of electric appliances, but if a radio receiver be installed the loud speaker produces most unpleasant noises. This is often attributed quite wrongly to some fault in the set. In many cases the noises are got rid of by having the electric wiring overhauled. According to a paper in the Electrical Review of June 1 by V. Z. de Ferranti, many domestic electrical appliances also cause bad radio reception. As examples he gives electric bells operated from the mains, children's electric toy trains, a bad contact in an electric fire and, worst of all, any piece of equip ment driven by a motor. He points out that it is far easier to supply equipment which can be trusted to cause no interference than to eliminate by special devices the interference caused by equipment already installed. The special devices are often expensive. He estimates that there are now two and a half million mains-operated radio sets in Great Britain. Collectively, they take about 150,000 kilowatts and the average demand is about two hours a day. In addition, the demand for this load is outside the busy hour of supply and it is therefore desirable to the electricity companies. There is quite an appreciable number of small house-holders who have availed themselves of electric supply primarily in order to be able to use it for radio receiving sets.

\section{Secret Radio-telephony}

A ScIence Service Mail Report dated May 28 states that Dr. S. Chiba, of the Tokyo Electric Co., has developed a secret method of radio-telephonic communication. According to the description, the 
sending installation employs a microphone so constructed that the speech current is inverted with respect to frequency, so that it is unintelligible to the listener on an ordinary receiver. At the receiving end of the communication channel an equipment is used to turn the speech back to normal. From these brief details, it would appear that the system is similar to the inverted-speech method employed by the British Post Office for securing secrecy, as an alternative to the speech-scrambling method which has also been developed and used by the Post Office in long-distance radio-telephonic communication.

\section{Research on Lawns}

IT is gratifying to learn that the British Board of Greenkeeping Research will be enabled to maintain its Research Station at St. Ives, Bingley, Yorks, for a further period of five years. Vol. 10, No. 3 of the Board's Journal contains a review by the Director of the past four and a half years' work at the Station. There is also a continuation of the series of articles by Mr. I. G. Lewis, describing common grasses. Redtop (Agrostis stolonifera, L., var. gigantea, Koch) and velvet bent ( $A$. canina) are considered in the present volume. The former is somewhat coarse for fine lawns, but the latter is the queen of putting green orasses. Mr. Arthur Hill describes his experiments on lawns at Craibstone, whilst the Director of the Bingley Station, Mr. R. B. Dawson, continues his articles on "Common Weeds of Turf". Dr. T. W. Evans also contributes a paper on phosphatic fertilisers in relation to greenkeeping, and Mr. R. Gordon, of Prestwick Golf Club, writes on "A Golf Course under Seaside Conditions".

\section{Royal Society of New Zealand}

THE inaugural meeting of the newly formed Royal Society of New Zealand (hitherto called the New Zealand Institute) was held at Wellington on May 16, when the presidential address was delivered by Prof. R. Speight, professor of geology at Canterbury College, Christchurch, New Zealand. Lord Bledisloe, the Governor-General of New Zealand, in a written address to the Society, intimated His Majesty's approval of the new designation of the Dominion's chief organisation for the promotion of science. The New Zealand Institute was founded in 1867 and the fellowship of the new Society is held by forty-eight men of science. In his address, Lord Bledisloe emphasised the importance of science in solving the world's economic and social problems. Only by the further application of science in all its ramifications and a more enlightened recognition of its beneficent potentialities by the world's rulers will effective remedies for current human disorders be found. The New Zealand Institute has achieved a high prestige in a land of immeasurable opportunities for industrial and cultural expansion. It is therefore to be hoped that under its new appellation it will enjoy to an ever-increasing extent the confidence and respect of the community at large.

\section{Dorothy Temple Cross Fellowships in Tuberculosis}

The Medical Research Council has made the following awards of Dorothy Temple Cross Fellowships for 1934-35, under the terms of the benefaction in that name for research fellowships in tuberculosis : Mr. W. S. Creer, Lady Jones Orthopædic research fellow, University of Liverpool ; Mr. A. W. Franklin, chief assistant to Children's Department, St. Bartholomew's Hospital, London; Dr. P. D'A. Hart, assistant physician, University College Hospital, London ; Mr. A. Landau, house physician, Brompton Hospital, London: Mr. A. H. T. Robb-Smith, senior demonstrator of morbid anatomy, St. Bartholomew's Hospital, London. Mr. Robb-Smith's fellowship is tenable in Germany, the others at centres in the United States. In addition, the fellowship awarded last year to Dr. G. G. Kayne for work at centres in Europe has been renewed for a further period of six months.

\section{Books on Social History and Early Travel}

Messrs. Francis Edwards's Catalogue No. 572 of new and second-hand books on "History throughout the Ages" contains items of even more extended interest than the title suggests. Not only does it include source books, but also in its extra-European sections there are a number of early travel books and other works of value for their early records of ethnographical material. Among items of particular interest to the social historian is a remarkable run of the London Gazette, Nos. 1-4825, dating from November, 1665 to March 24, 1710, in thirteen folio volumes, in contemporary calf. The early numbers include notices of the Plague, indicating the rapid decrease then showing in the figures. The accounts of the Fire of London are followed by schemes for rebuilding the city. Another item of similar interest is Higden's "Polychronicon" in the Rolls Series, now partly out of print. Among official papers is a complete set of the reports of the Historical Manuscripts Commission to 1926. An editio princeps of the Nuremburg Chronicle in Gothic letter of 1493 contains 1800 woodcuts, among which appears a portrait of Pope Joan. Early travel books include Hakluyt in black letter, the "Relations" of the Jesuits in Canada (1858), Burney's South Seas, Callander's Australian voyages, Formander's "Account of the Polynesian Race", Dalrymple's voyages in the South Pacific and Kæmpfer's history of Japan.

\section{Percival Collection of Seeds of British Plants}

THE Department of Agricultural Botany of the University of Reading has acquired the Percival Collection of seeds of British plants. This collection, which took about forty years to put together, contains mounted and named seeds of more than a thousand species. Although the British flora is not completely represented, the collection is by far the most adequate in Great Britain and is invaluable for reference purposes. Prof. W. B. Brierley, professor of botany at Reading, hopes that field botanists will 